\title{
Comparative Law, Geopolitics, and the Conflict in Palestine: Disciplined Disengagement and the Commons Solution
}

\author{
${ }^{1}$ University of Turin, Turin, Italy, E-mail: ugo.mattei@unito.it \\ ${ }^{2}$ UC Hastings College of the Law, San Francisco, CA, United States of America, E-mail: ugo.mattei@unito.it
}

DOI: $10.1515 / g j-2018-0008$

\begin{abstract}
Article Notes: Alfred and Hanna Fromm Distinguished Professor of International and Comparative Law at University of California, Hastings College of the Law, Professor of Civil Law and Fellow at Collegio Carlo Alberto University of Turin, and Academic Coordinator at International University College of Turin. This paper was presented at the Conference on Legal Aspects of the Israel Palestinian Conflict at the University of Turin on 10 March 2017 and as a keynote address at the University College Cork Conference on International Law and the State of Israel, March 31 - 2 April 2017.
\end{abstract}

[S]o long as people are guilty of crimes and perpetrate them, judgment is essential ... There must be judges. There must be law. Law must be enforced and law should be universal ... I think it's always embarrassing if the judge is someone who himself doesn't suffer from the action or is someone who has just won the battle. ${ }^{1}$

\section{Aims and structure of this paper}

I have three overarching theoretical points I want to make in this paper that inspire my motivation to discuss, in the context of comparative law, plunder in Palestine. ${ }^{2}$

First, I consider the Middle Eastern tragedy a structural aspect of the capitalist extractive mode and the victims of brutality by Israel similar to those victimized by European countries and the United States in other Middle Eastern theaters and elsewhere. Apartheid is alive and well as one of the ways a white minority rules the global majority of color, the global north rules the global south, and the rich rule the poor. ${ }^{3}$ I consider Zionism and its victims a manifestation of an unfortunate rule rather than an exception in the global scenario. ${ }^{4}$ I believe that the rhetoric of Israeli exceptionalism introduces a degree of parochialism into the traditional discussion on the Israeli-Palestinian conflict that does not address-either theoretically or politically-the cause of its victims. ${ }^{5}$ A dialogue in the context of comparative law should inform a more cosmopolitan approach. ${ }^{6}$

My second motivation is to demonstrate, through an examination of the history of comparative law and its particular attitude towards Israel, that while imperialism is a structural component of capitalism ${ }^{7}$ it is also a consequence of the choice of consolidating socialism within one country, as Joseph Stalin and Nikolai Bukharin did in the Union of Soviet Socialist Republics in 1924 and 1925. Imperialism is a consequence of power concentration, shared by the form of modern state capitalism called realized socialism. ${ }^{8}$ The Zionist project could not have been successful without the massive delivery of weapons by the Soviet Bloc and I consequently believe that responsibility for plunder in Palestine must be shared by both combatants in the "long Cold War."

Zionism belongs to the Western project of nationalism, with its capacity to deploy the powerful idea of the nation state. I think that a hardnosed reflection on the role and responsibilities of the Soviet Bloc and of the Western left in causing and legitimizing the Palestinian $N a k b a^{10}$ is very important for cosmopolitan truth and understanding. It also informs a better critique of the comparative law project and its Orientalism. ${ }^{11}$

Thirdly, I would like to show how the cultural construction of Israel as a state endowed with a so-called mixed legal system ${ }^{12}$ is a classic case of the West's imposition of its own values of modernity on communities elsewhere long living together in relative peace. A Western rulebook of ideas and institutions (including the very notion of a sovereign territorial state) has determined Middle Eastern power centralization. ${ }^{13}$ This particular colonial project, as every other one, has been anointed with legitimacy by the early rhetoric of civilization (and lack thereof), later supplanted by notions of democracy and the rule of law. According to such rhetoric, 
locals are uncivilized because they do not understand individual exclusive property law, the only "rational" form of private law. They cannot be part of the "civilized nations" because they have no states, the only legitimate producers of positive law. Plunder is therefore legitimized as a civilizing mission, in the mode of the Wilsonian white man's burden, ${ }^{14}$ because it brings progress and prosperity, to the point of allowing the desert to bloom. Consequently, the whole narrative of legitimacy has been cast in individual-centered and professionalized terms, erasing the commons-based laws of previously stateless local communities. ${ }^{15}$

After discussion of these three issues, I will try to sketch a pars construens of this paper where I argue that comparative law, in order to contribute to a resilient legal culture, should devote time to understanding such commons-based vernacular institutions, thereby providing materials for overcoming the current pedestrian alternatives of the Two-State and One-State solutions to the Israeli-Palestinian tragedy.

The author acknowledges that this paper does not address in detail the histories of the foundation of the Zionist movement (beginning in the late nineteenth century), 1915 Hussein-McMahon Correspondence, 1916 Sykes-Picot Agreement, or 1917 Balfour Declaration, on the one hand, or-after 1948 — what Israelis call the 1967 Six Day War and Palestinians call al-Naksah (Setback), 1973 Yom Kippur/Ramadan War, 1982 killings of 2,000 unarmed Palestinians in the Sabra and Shatila refugee camps by Israel-allied Christian militias, 1987 Palestinian Intifada (Uprising) in the West Bank and Gaza, 2000 al-Aqsa Intifada, 2014 Israel-Gaza assault, myriad failed diplomatic endeavors, or other important events on the timeline of the more than 100-year history of the IsraeliPalestinian conflict. These are intentional dialectic abstractions in the modes of extension and vantage point: this paper is - first and last—about comparative law, capitalism, and imperialism, not history or anthropology. ${ }^{16}$

Furthermore, as the late Belgian Marxist historian Marcel Liebman-in an essay about the flaws in the Zionist formulation of "A country without a people for a people without a country" — writes:

It is not here a question of invoking the past and searching about in it out of pure love of history, or in order to go back to the ultimate beginnings of an injustice: what is important is to show the constancy of a policy, the permanence of a kind of logic, the continuity of a situation which are now manifesting more gravely than ever before their baneful consequences. ${ }^{17}$

Palestine, once having been understood as a victim of Western intervention for plunder, could become a laboratory for experimentation of commons-based solutions organized in a loose ecological network. Such commonsbased No-State solution, I argue, could serve the interests of the people rather than those of the global conformation of power, successor of the national territorial state that takes the form of the military-industrialtechnological complex profiting from war and devastation. ${ }^{18}$

Modernity and its institutions_-including international law-are without resonance with the people of the Middle East. Perhaps, after the point of no return determined by the institutions of extraction, new solutions based on ecology and the commons rather than on markets and the state might regenerate the social fabric. ${ }^{19}$ Once again, the Fertile Crescent of the Middle East could become the crib for a new civilization.

\section{Plunder in palestine}

On 15 May 1948, Britain relinquished sovereignty exercised through a mandate over Palestine; Plan D (Plan Dalet), embraced two months earlier by David Ben-Gurion and his aides at the Tel Aviv headquarters of Haganah-with its compulsory Jewish conscription-was already in full gear. Plan D was a strategy to de-Arabize Palestine: to cleanse it from its aboriginal inhabitants in order to allow the settlement of Jews. ${ }^{20}$ Among many Palestinian villages attacked by Zionist forces of the Haganah, Irgun, and LEHI, ${ }^{21}$ later to form the official Army of the newborn Zionist State (Israel Defense Forces "IDF"), Haifa was a thriving Palestinian city from which Arab inhabitants were removed in April with British assistance. Upon the Israeli Declaration of Independence, more than 250,000 Palestinians were already gone: their land and businesses were destroyed or transferred into Zionist hands. All together, the establishment of the State of Israel (War of Independence to Zionists /Nakba to Palestinians) eradicated almost 800,000 Palestinians, destroyed 531 villages, and rendered eleven urban neighborhoods free of Arabs.

Very soon thereafter, property law - a Western legal institution that invariably plays a starring role in the legitimization of Western plunder - made its appearance in Israel. Under the Absentees' Property Law, 57101950, a custodian was granted control of land owned during Israel's War of Independence by any person who was (1) a citizen or subject of a country that fought, or sent troops to fight, against Israel during the War (Lebanon, Egypt, Syria, Saudi Arabia, Trans-Jordan, Iraq, and Yemen), (2) present in one of these countries during the War, (3) present during the War in a portion of the area of the British Mandate that was not included in the State of Israel, (4) a citizen or resident of the British Mandate who left her place of residence during the War to live outside of the area of the mandate, or (5) a citizen or resident of the British Mandate who left to 
live in an area formerly included in the British Mandate but then held by the countries that fought against the establishment of the State of Israel (after the War, Egypt, Jordan, and Syria each took possession of a portion of the area of the British Mandate that the United Nations had designed for a separate Palestinian State). ${ }^{22}$

Such land, which according to the Absentees' Property Law was held in "custody for owners," was in fact plundered from legitimate Palestinian owners whom the enacting State of Israel constantly precluded from returning. Later, it was transferred to the Israeli Development Authority ("IDA") and became one of the components of the publicly owned land of Israel.

It is a basic law of Israel (sometimes heralded as a proof of the socialist inclination of the Zionist movement) that land-93\% publicly owned in Israel—is inalienable and falls into three categories:

- owned by the State

- owned by the Jewish National Fund ("JNF")

- owned by the IDA

Therefore, technically speaking, no physical person owns the land, which is a classic structure of colonial property law (as well as traditional English land law) that has very little to do with being socialist. ${ }^{23}$ Rather, such an arrangement grants the Israeli Government the power to prevent non-Jews from buying land, deploying a strategy of Zionism dating back to the late nineteenth century. Zionists have gained propaganda mileage from their claim of having "purchased" the land from the Arabs; in fact, the portion of Palestine so acquired was a mere 5\%-6\%.

Many intellectuals remain in denial of Ilan Pappé's highly documented description of Plan D (and of the predecessor Plans A, B, and C) as a planned Zionist ethnic cleansing of Palestine (see footnote 21 above). Prominent Israeli historian Professor Benny Morris, for example, imagines the voluntary displacement of the Palestinians. ${ }^{24}$ By now, however, many scholars are at least skeptical of the narrative of voluntary exodus by the Palestinians to permit the military forces of Arab neighbors to invade the newborn State of Israel. ${ }^{25}$

Dispossession, murder, and plunder have been going on for a long time in Palestine, even before the UN proposal of partition of Palestine in November 1947 that granted $56 \%$ of the territory to a Zionist State and the rest to a Palestinian State that never came to existence ${ }^{26}$ (a plan that the Zionists accepted, almost certainly after being sure the majority of the Arab States would reject it). In any event, the Palestinian people never really had a chance to decide about its being de facto obliterated in favor of self-interested neighboring states. The UN partition plan was severely flawed and granted the bigger and better slice of the contentious pie to the tiny Jewish minority who then owned through JNF only about $5 \%$ of historic Palestine.

Much more revealing is the role of "exclusion" as a fundamental aspect of both public and privately held land, introduced into Palestine by the Zionists. This modern notion of ownership (as well as that of state) was foreign to previous Palestinian law of property ${ }^{27}$ and was responsible for the tensions generating the clashes of the 1920s and of 1936. Even when privately and not communally held, agricultural land was never exclusive in Palestine. As in Medieval Europe, the peasant communities came with the land and could inhabit and cultivate it under the protection (sometimes the yoke) of an often-absentee landlord élite.

When Ashkenazi ${ }^{28}$ Zionists bought Palestinian land, often from such absentee owners, they brought with them the idea of exclusion already codified in Europe. Accordingly, their instinctive behavior was to evict the Palestinian peasants, as it was the documented policy of the JNF, the largest land purchaser. Titles of acquired ownership displayed to the tenants to evict them were ununderstandable in form and substance to the peasants, who were used to having masters who would allow them to cultivate the land rather than leaving it idle for future occupation. This clash was the old, old story: very similar transactions occurred in colonial Latin America and Africa and this had been the sine qua non of enclosure and property modernization in Europe since at least the sixteenth century. ${ }^{29}$

\section{Impotence of international law}

For a jurist, the conflict over state territory is not structurally different from that between two landowners both claiming exclusivity over the same piece of land. Since the development of modern international law by Hugo Grotius, a conflict over territory (where exclusive Westphalian sovereignty is involved) is a classic issue that can be legally determined. Modern notions of national sovereignty (from Jean Bodin to Thomas Hobbes) have always deployed stylized notions of Roman dominium to characterize the exclusivity of the claim of the nation state. ${ }^{30}$ And, to be sure, if one reads the International Court of Justice ("ICJ") self-presentation, she would be quite persuaded that a legal forum for such classic disputes were available also for Palestinian rights after the 
foundation of the UN with the establishment of the ICJ in 1946: "The Court's role is to settle, in accordance with international law, legal disputes submitted to it by States."31

Unfortunately, the law never helped in deciding the dispute between two nations-the Palestinians and the Zionists-over that small part of the Middle East called Palestine. The former was not recognized as an independent state (although a limited Vatican-like recognition was granted in 2012) ${ }^{32}$ while the latter obtained statehood shortly after declaration of independence and garnered immediate recognition by the Cold War superpowers.

Failing to be part of the solution, the law became part of the problem because it introduced into the already complicated puzzle all the issues of Orientalism, racism, identity, and self-indulging narrative that are part of the Western rhetoric on democracy and the rule of law.

To be sure, a large literature characterizes activities perpetrated under the color of the Zionist project as war crimes, perhaps even as crimes against humanity. However, I do not find it useful to discuss Plan D deploying the lingo and the aspirations of international legality that the UN was born to construct in the aftermath of the tragedy of World War II. I consider such formal legal notions belonging to a domain of transcendence: I prefer to observe the reality of the conflict on Palestine within the much more trivial, material, and therefore immanent notion of plunder as developed in Plunder: WHEN THE Rule of LAW Is ILLEgAL. ${ }^{33}$ It is in this perspective that the law, setting aside the hypocritical veil of wishful thinking, reveals its true nature: a Western ideological apparatus providing legitimacy to the rule of the stronger.

The rule of law has been, throughout the history of the relationship of the West with the Rest, a powerful machinery of domination characterizing the Rest as lacking the rule of law and thus legitimizing Western plunder. The commitment of the Israeli legal community to be part of the West and the investment of the State of Israel in a strong "rule of law" identity are crucial and often neglected components in the history of plunder in Palestine. ${ }^{34}$ Politically incapable or unwilling to respect international law, Israel has nevertheless massively invested in building for itself an internationally recognized and well connected legal culture participating actively in the international effort of making comparative law a sibling discipline of international law in the global legal academy.

\section{Role of comparative law in normalizing plunder in palestine}

The ICJ was established by treaty as part of the UN system right after World War II in 1945; it began its operations in 1946. Article 38 of the treaty contains the official list of the "Sources of International Law." Among them, after customary law and treatises, are "[c]ommon principles recognized by the civilized nations."

Ascertaining such common principles became one of the most important endeavors of comparative law, perhaps a reason why this relatively new branch of international legal studies came of age around 1950, trying to show the existence of areas of convergence at a level deeper than the "political," even between Soviet law and capitalist law. ${ }^{35}$ Clearly, the effort of the international legal community to understand through comparative law the principles common to the "civilized" nations postulated a cryptic assumption of what was civilized and what was not, something that in an era of still rampant colonialism was necessarily tainted by Orientalism (in the sense of Palestinian scholar Edward Said). ${ }^{36}$

The selection of the countries whose laws would be compared in order to ascertain the existence of "[c]ommon principles" became a crucial activity of cultural legitimization of a legal system as civilized. ${ }^{37}$ This selection was not especially problematic for the countries belonging to the two major Western legal traditionsthe common law and the civil law. Every legal taxonomy used by comparative law scholars to group loosely together countries being part of the same legal family included both core and peripheral countries of the two major legal families (now known as legal origins). ${ }^{38}$ In a sense, the closer to the core the closer to civilization, being the legal heart of the very identity of Europe and the West. A variety of techniques were developed over time by comparative lawyers to see commonalities between common law and civil law-no matter their staggering technical differences - but since the very beginning it was assumed that whatever was common across the great divide of Western law was, by definition, civilized. ${ }^{39}$ Thus, being Western became synonymous with being civilized.

Comparative law came of age as a scholarly discipline around the years of the foundation of the State of Israel under Cold-War conditions. As I have shown elsewhere, one important incentive to the reaching of this scholarly maturity was the major challenge of socialist law claiming, through a variety of epigones of the great jurist Evgeny Pashukanis, the non-comparability of law across the capitalist vs. socialist divide. By 1950, the issue was largely resolved, Pashukanis executed, and socialist law was already becoming the third family of modern legal systems, after the civil law and the common law. The major topical books (David, Zweigert \& Koetz, and Schlesinger), which were posing the discipline of comparative law on sounder jurisprudential grounds than 
the previous black letter tradition of Legislation Comparé, all recognized socialist law as a modern legal system with its own original characteristics of a model of "socialist legality." 40

As Teemu Ruskola has demonstrated, the early tradition of comparative law was highly Orientalist (as was also the case of Karl Marx). Not only the laws of China, India, and Africa, but also the whole tradition of Islamic law suffered this attitude. Through the second half of the last century, the legal systems of these countries were grouped together in a sort of intellectual dump, of "other conceptions of" law, that almost by definition were unable to contribute in the making of an international rule of law (being stuck in religious or traditional premodern conceptions): these countries were not described for their positive attitudes but for what they lacked, i. e., the rule of law.

As a consequence of this general attitude, quite coherently within the overall Zionist project of considering Israel an oasis of Western civilization surrounded by less civilized people, the laws of Israel were described as the only successors to the British Mandate over Palestine.${ }^{41}$ Palestine itself lacked all real importance in the Ottoman world, which left it sparsely populated and impoverished. For comparative law, the succession was Ottoman Islamic law, English common law, Israeli law, itself fertilizing not only the desert but also the English legal tradition through an injection of highly sophisticated civil law doctrine brought in by Ashkenazi jurists from Italy, Poland, and Germany. Because of such layer of civil law tradition on a common law foundation, Israel became a classic example of a mixed legal system working out original hybrid solutions highly interesting in a global legal landscape that was beginning its process of Americanization.

Consequently, the international legal community had quite a lot to learn from the Israeli legal experience of merging the common law and civil law traditions. In areas such as judicial lawmaking, property law, and (even) constitutional law, ${ }^{42}$ Israel was generally perceived by the international legal culture as a highly advanced experiment, not only "the only democracy in the Middle East" but also the only system based on a rule of law of a quite superior mixed quality. ${ }^{43}$ This highly sophisticated hybrid of the law was contributing to erase every previous and contemporary legal experience in Palestine as much as the substance of plunder, thus normalizing Israel in spite of all its own issues of international legality that an unbiased observation would have pointed out. $^{44}$

\section{Plunder in palestine: an exception or the rule?}

The international legal community has long been an accomplice in practices of international plunder so that it would be quite naïve to single out its benevolent attitude toward Israel as a special scandal per se. Plunder is the rule practically everywhere in the relationship of the West with the Rest and in Palestine it is historically documented in great detail from the Roman destruction of the Temple through the Crusades.

True, there are a few specificities in the modern Palestinian situation that make such attitude especially problematic. The quite recent historical moment makes the Israeli actions against the Palestinian people more difficult to legitimize by law than those by the European colonists in the Americas or during the scramble for Africa. In the mid-twentieth century, the fundamental fiction of law as a positivistic order separated from politics - and thus to be studied and understood in its own terms by politically neutral and formalist juristswas challenged by sociological jurisprudence, realism, and a variety of anti-formalist movements. Lawyers could no longer feel excused when ignoring political realities. The intimately political activity of state creation is essentially a legal construction when it passes from the constituent to the constituted. Thus, it is singular that most of the entries on Israel in international legal encyclopedias deploy a strategy of full normalization with no mention whatsoever that most of the territory of the state (a constituent element of the very notion of statehood) is either contested or occupied plainly against the law. ${ }^{45}$

Indeed, Israeli law has obtained a privileged status through the aforementioned notion of a paradoxically unchallenged idea of a "mixed legal system," civilized by definition, being the crossing point between the civil law and the common law tradition. By such strategy, legal scholars have described the law of Palestine, a portion of the Middle Eastern territory inhabited mostly by Muslim Arabs, as belonging to the Western legal tradition (a concept in the making at the time) as opposed to all the other countries of the Middle East being classified within the residual category of "other conceptions of" law.

This demonstrates an attitude of the international legal community's being trapped in a cognitive bias in favor of the Zionist project, especially because the notion of the Western legal tradition was developed through the highly positivistic move of separating law from politics and from religion. ${ }^{46}$

Any unbiased observation of the law of Palestine/Israel, from the Nakba to present, evidences a legal system flatly in opposition to the separations among law, politics, and religion recognized as the essence of Western law. Indeed, most of the territory of Palestine remains under a military rule of occupation and subject to a state of emergency, repeatedly deemed contrary to international law, whose perpetuation has been possible only 
because of geopolitical reasons. ${ }^{47}$ This shows clearly the hegemonic role of politics in the law of Palestine/Israel. ${ }^{48}$

Moreover, the very act of establishment of the State of Israel as reflected by its legal system was religious. Denying the religious nature of the Zionist colonial project and the consequent structure of the Zionist State would be an untenable position. Even if the declared principle of non-discrimination on the ground of religion, contained in the fundamental laws of Israel, were not routinely violated by the law in action, the Jewishness in the defining of Israeli citizenship renders Israeli law much closer to religious law than to a genuine Western legal system. Conversion to Judaism is a ground for claiming citizenship and this fact alone supports the current description of the different status in Israel between Jews and non-Jews as a regime of apartheid. ${ }^{49}$

However, through the notion of a mixed legal system of common law and civil law components, the international legal culture has participated in the project of inventing Israel as a Western legal system, civilized per se (notwithstanding the practices of colonial plunder and the crimes perpetrated by the executors of the Zionist project). ${ }^{50}$ The origins of the law in mixed legal systems are either the common law or the civil law: anything else is no law, does not exist, or can be erased. To be sure, invariably the narrative on Israel begins with the British Mandate's introducing the common law tradition to make good the failed Ottoman religious (Muslim) legal system. ${ }^{51}$

The outcome of this intellectual construction, whether in good or bad faith, ${ }^{52}$ has been the erasure of the deep Palestinian layer of the law of Palestine/Israel, an erasure that has deployed, as in other historical experiences of colonial plunder, the notion of empty land and civilization.

Thus, the construction of Israeli law as an advanced and sophisticated example of a mixed Western legal system (now moving toward US law) is like the building of the beautiful forests that JNF has planted over the ruins of the Palestinian villages destroyed during the Nakba. It is the invention of a Western legal enclave of civilization, ${ }^{53}$ within the obscurantist world of "the Islamic legal tradition." This attitude reproduces, well within the twenty-first century, the old practices through which lawyers have served as agents of legitimacy for plunder at home and abroad. ${ }^{4}$

As Roberto Esposito (one of the leading philosophers of the Italian theory) has recently written, Europe (i.e., the West) has always projected its own issues outside of its borders, in a process of denial of its own predicaments. The building of Fortress Israel, enclave of Western legal civilization within "savage" territory, is exactly such a move and we must understand it as such. Centuries after the conquistadores and more than a century after the scramble for Africa, the music has not changed. Israel is not outside of the West today; it is, in its intimately internal essence, the polar opposite of our (congratulatory) self-perception based on the rule of law. "Our" Fortress Israel is not only the shame (and the nightmare) of the Israelis living in denial of the crimes and atrocities of their own founding fathers, the very same ones who "made the desert blossom." It is also our own shame and nightmare, surrounded as we are (just like Fortress Israel) by impoverished masses created by our very project of domination and plunder that now because of the "iron laws of demography" endangers the purity of our order based on the rule of law. ${ }^{55}$

\section{Who are the guilty parties?}

Israel is no exception. It is the proxy of the West in its oppressive attitude toward the Rest. It is the whole project of modernity-including its advanced socialist form that develops into imperialism-that should stand the trial of history. The impossibility to find a peaceful solution to the tragedy in Palestine, without a revolutionary change of attitude, is the metaphor for finding a future and a survival strategy without overcoming the paradigm that has morphed into a savage assault on the mechanisms of reproduction of life on Earth. ${ }^{56}$

Unfortunately, modernity is not just Western capitalism but also its socialist spinoff that, while generating hopes for emancipation, has embraced structures and policies that in the Middle East are difficult to distinguish from imperialism as an advanced development of capitalism.

Any unbiased discussion of the "making" of Israel and of its invention as a Western law of Palestine covering under a colonial project a whole civilization (including a legal civilization) requires coping with the issue of the relationship between socialism and colonialism-imperialism.

To be sure, both the Israeli victory in the 1948 war and the full execution of Plan Dalet were made possible because of heavy weapons (including aviation) provided by the Soviets through Czechoslovakia. In May 1948, the Israeli Army received a major supply of modern 0.45 cannons, an example of the endowment of Israel with an artillery superior to that of the Arab troops not only in Palestine but also in all Arab countries combined. ${ }^{57}$

The nature of the Zionist project was spelled out by Ben-Gurion, who euphorically annotated in his diary that same day a full-fledged project of Western colonialism-imperialism, going beyond Jewishness and with roots in pre-Islamic issues: 
We will establish a Christian State in Lebanon, whose southern border will be the Litani River. We will bend Transjordan, we will bomb Amman and destroy its Army and at that point Syria will collapse; if this notwithstanding Egypt will continue to fight we will bomb Port Said, Alexandria and Cairo. This will be our vengeance for what they (Egyptians, Aramaics and Assyrians) did to our ancestors at the time of the Bible. ${ }^{58}$

Having received the weapons from the Soviets, Ben-Gurion and his aides ordered the 12 brigades of the Army to consider occupation of the West Bank, the Golan Heights, and Southern Lebanon.

The issue of the impact of the Cold War (which officially started with the so-called Truman Doctrine in $1947)^{59}$ on the Middle East and on the attitude to the Zionist project in particular is very complex and goes well beyond the scope of this paper. Certainly, as mentioned above, both superpowers recognized the State of Israel immediately and the perception that Zionism was a "socialist" project (especially because of the early kibbutzim movement) remained rooted in the European left for quite a long time. ${ }^{60}$

Possibly, supporting the Israeli War of Independence was a tactical move on Stalin's part to weaken the British imperialist presence in the Middle East, since England was the foe of unlimited Jewish immigration in Palestine through World War II. As late as 1939, in spite of the Balfour Declaration (that in a lawyer's interpretation was made to say much more than it actually did), Britain officially declared that Palestine should not become a Jewish State. Consequently, England was the target, together with the Arabs, of the Irgun's attacks. Such attacks included the 1946 bombing of the British headquarters at the King David Hotel in Jerusalem. ${ }^{61}$

The strength of the Communist Party in Israel is certainly part of the story as it probably was the sympathy of the Grand Mufti of Jerusalem (at the time, the highest Palestinian authority) toward the governments of the Axis that tainted somewhat the anti-Zionist Arab revolts of 1936. Another explanation of Communist early attitudes toward Israel might have been the fact that it was the Red Army to arrive first at Auschwitz, thus perceiving the full-fledged horrors of the Holocaust, that Israel was quite effective to exploit when its own turn came to impose astonishing suffering upon innocent populations for ethnic reasons. The anti-Jewish pogroms in pre-revolutionary Russia were not only instrumental to the birth of early Zionist doctrine but also generated much of the early Ashkenazi influx of settlement in Palestine. Moreover, the desire to show the world a clear-cut change in Soviet Russian attitudes towards Jews also motivated Stalin's early policy. ${ }^{62}$

However, it is a fact that shortly after recognition, the Soviet sympathy towards Israel declined somewhat with the beginning of US hegemony that enormously increased also thanks to the prestige of the Zionist Organization of America, chaired by the famous jurist Louis Brandeis.

Comparative lawyers have emphasized the socialist roots of Israel: Israel is not only a secular mixed legal system but also a "progressive" one. Moreover, Cold War conditions determined the coming to maturity of comparative law as an academic project. Similarly, "Cold-War driven" is the development of a concept of Western legal tradition that made the ideology of the rule of law a tremendously powerful tool in the post-war global success of US law. ${ }^{63}$

Interestingly, during Cold War confrontation (although with variable intensity) the rule of law was constructed on both sides of the Iron Curtain as a powerful separating device between bourgeois law and socialist legality to the point of denying any dialogue or even comparability of socialist and bourgeois law (following both the Marx/Pashukanis orthodoxy and Andréi Yanuárievich Vyshinski's Stalinist version). Nonetheless, at the Nuremberg Trials-when the Holocaust became a legal fact generating responsibility for its perpetrators-comparative law was deployed in practice and included a dialogue on legal principles between the US and Soviet delegations. Clearly, at Nuremberg, some remarkable convergence took place. ${ }^{64}$ The tradition of the winner's trials to history was inaugurated there and the "Jewish question" was displayed in its DNA. ${ }^{65}$ The suffering of Jews during the Holocaust has thus determined some sort of special status for Israel in international law, a privilege - in the etymological sense of private law — that Israel claimed due to its (unquantifiable) risk of destruction.

When it comes to the law, Zionists, Communists, and Western liberals proved to be more united by the modernist project (with its obsession of putting the state at the center of the legal picture) than divided by their political divisions and interests.

Israel was now a recognized state and its legal system was to be described and understood within the positivistic professional attitude. ${ }^{66}$

\section{Think outside the state-centered box}

Sirin was a Palestinian village (close to the limits of the Negev Desert) whose system of shared land tenure, according to the description offered by Ilan Pappé, created the legal conditions for the development of a little heaven in the middle of a very harsh climate. It was destroyed in 1948. 
In Haifa and many other cities, open communities of Palestinians, other Arabs, Jews, Christians, and Muslims lived for centuries side by side developing trade, crafts, arts, culture, and customs-and, therefore, laws governing such activities-before Western plunder, in the form of Zionism, disrupted these institutions of commoning. ${ }^{67}$ To be sure, Islamic law owed since antiquity much to Jewish law and these two religious legal traditions, seen in comparative perspective, share principles, style, and fundamental values. ${ }^{68}$ Institutions such as the Islamic Waqf and other antique systems of tenure and obligations were there to protect the poor and what Westerners today call the "interests of future generations," thus "reinventing the wheel" in our attempt to set limits on the tyranny of exclusion determined by a structure of capitalist property law, which enlightened jurisprudence finally understands as unsustainable. ${ }^{69}$

As we have seen, capitalist property law interpreted as pure exclusion was introduced in Palestine by Zionist (and perhaps British) colonizers and served as a significant irritant to the peaceful village life quite early in the unfolding of the tragedy. Western conceptions of capitalist property law have been powerful weapons in the ideology of plunder since the Latin American Conquista. ${ }^{70}$ The destruction of life in Palestine before and after the Nakba has been ideologically supported by the same notion of uninhabited land: terra nullius owned by no one and therefore "up for grabs" by colonists, a concept always deployed against aboriginal people from America to Africa to Oceania. In Palestine, civilized Western European Jews were able to deploy the rhetoric of the Catholic Spaniards in Latin America, of the White Anglo Saxon Protestants in North America, and of the Dutch Afrikaans, French, Belgians, Portuguese, Germans, and Italians in their own respective targets of plunder. $^{71}$

In a perspective that is broad enough in time and space, what happened in the Nakba can be seen as part of a general consequence of legal modernization, that we can call the catastrophe of the commons (both rural and urban) and their complete substitution with two naturalized notions: exclusive private property and territorial state sovereignty. ${ }^{72}$ This is what Marx called the primitive accumulation, a phenomenon that is in fact the structural nature of capitalist extraction and requires seeing every episode not as an exception but as the rule. ${ }^{73}$

These two pillars of plunder-exclusive private property ownership and the sovereign state, the fundamental building blocks of Western rule of law-were as completely unknown to Palestine before Zionism as they were unknown to America and Africa before their own ages of plunder. Before plunder, Palestine (as America and Africa) was not empty, neither of people nor of law and institutions. It was populated by people whose legal ways were variable, contextual, sometimes highly sophisticated, and in tune with the local ecology: legal ways such as those that many legal anthropologists try to reconstruct ${ }^{74}$ and whose structure, broadly speaking, is that of customs making possible what Nobel Prize in Economics winner Elinor Ostrom called commoning. ${ }^{75}$

These aboriginal commons institutions are now covered, even in the local colonized imaginary, by the thick layer of the modernist "box" just as the destroyed Palestinian villages are covered by forests or by the campus of the University of Tel Aviv, the best clothing that plunder can wear to justify, dissimulate, or deny itself.

Because of this hiding or denial of the catastrophe of the commons, which is a regime of knowledge in the most classical sense, lawyers and politicians resist thinking outside the box of modernity: this is why no creative solution adapted to the circumstances has yet emerged. We consider utopian every thought outside the box, when it seems that utopian is in fact the insistence of looking at the problem as if it were the solution.

Commons institutions were capable of keeping Jews and Arabs together in peace not only in Palestine and the Middle East but also throughout Northern Africa, Sicily, and Spain before the events of the late fifteenth century. Since the state and the centralization of power emerged onto the world stage, however, this has been a forlorn quest. ${ }^{76}$

Any international legal community committed to critical knowledge as a prerequisite for a permanent solution should not participate in the erasure of such commons institutions under a thick layer of ideology. Rather, like the archeologist digging for ruins of previous civilizations, the comparative legal scholar should explore below the most recent layer of modern rule of law ideology in order to unearth, rediscover, understand, compare, and make available to the legal culture of the world alternative arrangements that we are now seeking in theory but failing to obtain in practice: peace and justice.

There is no romanticism or nostalgia in this vision. There is only the realistic humble assumption that modernity has failed largely because of its laws, and that the rule of law's being a product of Western imperialism is the problem and as such cannot be part of the solution. ${ }^{77}$

In Palestine, the state and the rule of law ideology that it generates are foreign deadly intrusions just like a pollutant in a lake. The Zionist movement was based on Western notions of statehood: give a state to the Jewish people: "A country without a people for a people without a country." The current debate between One- and Two-State solutions of the conflict is still based on the Western notion of statehood. But, as said before, Western imposed institutions, being part of the problem, cannot be part of the solution and this seems the most compelling reason to look into a No-State solution for Palestine that we could call a commons solution. ${ }^{78}$

Today, the state is a particularly obsolete tool to tackle thorny political issues, especially if we idealize it as a tool for potential liberation of people: in fact, the state proves everywhere to be an instrument of oppression by 
the global élite of the masses. As an institution, it is weak with the strong (global corporations) and strong with the weak (the "99\%"). Palestine is no exception: seeking liberation through nationalism and state-centric visions is just an illusion, indeed a nostalgic romantic nationalist utopia. The growth of the military-industrial complex has reached proportions that Dwight Eisenhower could not have imagined when he denounced its risks in his famous 1961 farewell speech. ${ }^{79}$ Palestine and the Middle East are perhaps the most lucrative market that feeds this delirious global monster of corporate money and technological omnipotence. Private corporations, whose growth is unfettered, now dominate states. They work as massive machines of capital concentration supplanting, often through technology, what used to be state sovereignty.

The conflict in Palestine cannot be circumscribed in a box. It requires a general understanding of the evolving global capitalist system and geopolitics, something still absent today in Palestinian studies. Not only in play are states but also organized capital (for which states are merely disposable tools). Every day, we witness the failure of the West in the Middle East. Concentration of power and exclusion in order to transform commons into capital is its deeper structure. ${ }^{80}$

Do we want its reproduction in Palestine or might we more wisely, in order to "ma[k]e all the difference," travel "the road not taken"? ${ }^{81}$ It might well be that ecological and systemic thinking can offer some suggestions on what to do ... or at least of what not to do. Law is a living organism because it reflects the life of its users. ${ }^{82}$ Today, the law is dead in Palestine, having been killed by apartheid and ethnic cleansing perpetrated by the State of Israel..$^{83}$ As with the corpse of a dictator we are unable to live without, the death of law is not recognized in Israel. Rather, it is denied by dressing up the corpse in its most elegant clothing: a European progressive mixed legal system. This strategy of denial and self-congratulation is itself deadly. ${ }^{84}$

When a living ecosystem is devastated by an external intrusion, such as phosphates generating algae that kill a lake, the solution suggested by environmental scientists is to identify the intruder and protect a small portion of the ecosystem, say a small cove, from it. In a shorter time than one might expect, life is regenerated in that small part. From there, incrementally protecting other small portions, from the bottom up, little by little, life can be restored throughout the lake because the ecological communities are open and can rescue each other.

Once having identified capitalist plunder and its institutions as the problem, an analogous strategy could be considered for Palestine: making parts of it internationally protected and funding enclaves of community regeneration. In such enclaves, soon to become a network of cities and villages, Palestinian refugees might incrementally re-enter the community living side by side with open-minded Jewish Israelis engaging together in arts, crafts, and sustainable agriculture in a desperately needed virtuous experimentation in post-capitalist sharing society.

One could argue the kibbutz has already been such a non-capitalist organization of sharing that did not work as an incentive for peaceful relationships. ${ }^{85}$ However, the kibbutz is not an ecological community, which by its nature is open and hospitable, as were the early Palestinian villages and neighborhoods of towns and cities where Arabs and Jews once lived together in peace. The enclaves of legal regeneration must be open and ready to connect with similarly minded experiments producing a broad network without frontiers of communities sharing problems and solutions. This network of villages and cities will claim autonomy incrementally from vertical state arrangements, realizing ultimately the vision of commons without property and without states. ${ }^{86}$

Such experimentation would be extremely useful as well beyond the boundaries of Palestine, because the demand for living institutions to substitute the deadly ones framed in the interest of the military-industrial complex is strong today in many parts of the world suffering under neoliberal arrangements of individualization and corporate control of the political process. ${ }^{87}$ Of course, the dimensions of the constituent communities will limit the size of the network. Rather than being arbitrary (as the current sizes of most states and supranational organizations such as the European Union), it will be determined by the ecology of the places presumably linking together open communities sharing similar challenges and therefore interested in dealing with each other. This is where a new Mediterranean institutional dimension might ultimately emerge, creating a much needed living political dimension to substitute dead techno-bureaucracies such as the current EU. Indeed, the communities and the people of Southern Europe have so much more in common with those inhabiting the other side of the Mediterranean than with northern communities of Continental Europe.

Many new institutional arrangements are out there to explore once the West will find the courage of declaring the intellectual and political bankruptcy of its own project of modernization, including the many global legal narratives, like so much of comparative law that has accompanied and still supports its deadly unfolding.

\section{Acknowledgements}

The author thanks George Bisharat, Joseph Halevi, Teemu Ruskola, Laura Nader, and Elisabetta Grande for comments and suggestions. I am especially thankful to Ryan Fisher, JD from UC Hastings and PhD Candidate at UC Santa Barbara, for his tremendous help in finalization of this paper. 


\section{Notes}

1 Violinist and conductor Yehudi Menuhin, in the concluding moments of the four-and-one-half-hour documentary by MARCEL OpHULS, The Memory of Justice (Paramount Pictures 1976), a film exploring then-recently alleged war crimes in Algeria and Viêt Nam in the context of Nazi atrocities and related Nuremberg Trials and addressing national and individual guilt.

2 I use the notion of plunder as developed in Ugo Mattei \& Laura Nader, Plunder: When the Rule of Law Is Illegal (First ed. Blackwell Publ'g 2008).

3 For a discussion of apartheid, see Beyond Occupation: Apartheid, Colonialism and International Law in the Occupied Palestinian Territories (Virginia Tilley ed., Pluto Press 2012).

$4 \mathrm{Ibid}$. at 82-83, considering "replacement of previous law ... worse than capitulation."

5 For a brilliant challenge to such exceptionalism, see Lisa HajJar, Courting Conflict: The Israeli Military Court System in the West BANK AND Gaza (First ed. Univ. of Cal. Press 2005).

6 For a debate on the purposes of comparing laws, see Ugo A. Mattei, Teemu Ruskola \& Antonio Gidi, Schlesinger's Comparative Law: Cases, Text, Materials (Seventh ed. Found. Press 2009).

7 See Imperialism, the Highest Stage of Capitalism in Vladimir I. Lenin, Selected Works, Vol. 1 (Progress 1963), https://www.marxists.org/archive/lenin/works/1916/imp-hsc/.

8 See Guy Debord, La société du spectacle (First ed. Les Éditions Gallimard 1967), in which that author calls "realized socialism" the concentrated spectacle.

9 While the Cold War technically started in 1947, I use the term "long Cold War" to allude to the almost 75-year confrontation between socialist and capitalist law that started immediately after the October Revolution of 1917 and ended with the fall of the Soviet Union in 1991. See John Quigley, Soviet Legal Innovation and the Law of the Western World (First ed. Cambridge Univ. Press 2007).

10 Loss by Palestinians of the majority of their territory, destruction or abandonment of several hundred Palestinian settlements, and displacement of more than 700,000 Palestinians during the first Arab-Israeli war in 1948; see Plunder in Palestine below.

11 See, e. g., Teemu Ruskola, Legal Orientalism: China, the United States, and Modern Law (Harvard University Press 2013).

12 For a discussion of this concept, see Vernon V. Palmer, Mixed Jurisdictions Worldwide: The Third Legal Family (Second ed. Cambridge Univ. Press 2012).

13 See George Emile Bisharat, Palestinian lawyers and Israeli Rule: Law and Disorder in the West Bank (Reprint ed. Univ. of Tex. Press 2012). Both Bisharat and Hajjar, op. cit. supra, insist that the very existence of professional lawyering in Palestine has been in reaction to Zionist-imported stress on the rule of law: "It was Israel's enthusiasm for law and the ornate legalism of the official discourse that catalyzed the development of local human rights movement that served as harbinger of legalistic resistance" (49).

14 The White Man's Burden: The United States and the Philippine Islands is an 1899 poem by Rudyard Kipling about the American colonization of the Philippines in the Spanish American War: it has been embraced, in spite of its theme of Eurocentric racism, as an ideological justification for imperialism.

15 See Laura Nader, Culture and Dignity: Dialogues Between the Middle East and the West (First ed. Wiley-Blackwell 2012).

16 I embrace Laura Nader's opinion when she writes, "I think the reason Ugo Mattei and I were able to write the book [see footnote 3 above] together is he had no interest in being an anthropologist, and I had no interest in being a lawyer ..." Laura Nader, Law and Intercultural Competence, 26 Pac. McGeorge Grobal Bus. \& Dev. L. J. 123 (2013) (presented on 8 August 2011 at the 2011 Pacific McGeorge Workshop on Promoting Intercultural Legal Competence in Lake Tahoe, California) at 126.

17 Marcel Liebman, 7 Israel, Palestine and Zionism 89-109 (Brian Pearce trans., The Socialist Register 1970), http://www.socialistregister.com/index.php/srv/article/view/5292/2193, at 90.

18 See, e. g., Laura Westra, Faces of State Terrorism (Studies in Critical Social Sciences) (Reprint ed. Haymarket Books 2014).

19 See Michael Hardt o Antonio Negri, Commonwealth (Harvard Univ. Press 2009).

20 I rely, in this paragraph, on the data and evidence offered in the thoroughly documented first hand reconstruction of ILAN PAPPÉ, THE Ethnic Cleansing of Palestine (Reprint ed. Oneworld Publications 2007).

21 Lohamei Herut Israel, also known as the Stern Gang.

22 See Marcia Gelpe, The Israeli Legal System (Carolina Academic Press 2013) at 444-46.

23 See Ugo Mattei, Socialist and Non-Socialist Approaches to Land Law: Continuity and Change in Somalia and Other African States, 16 Rev. OF Socialist L. $17-55$ (1990), https://repository.uchastings.edu/cgi/viewcontent.cgi?referer= https: / / www.google.com / \&httpsredir=1\&article=2287\&context=faculty_scholarship.

24 See, e.g., Benny Morris, Israel and the Palestinians, ThE Irish TImes, 21 February 2008 (Opinion: Letter), https://www.irishtimes.com/opinion/letters/israel-and-the-palestinians-1.896017.

25 Public debates on the Israeli-Palestinian conflict are a recurring phenomenon in the Academy, particularly when this issue becomes topical based on a well-publicized military, political, or diplomatic event or on the contemporaneous publication of a book by at least one of the interlocutors. One infamous example (and subsequent feud) was the joint appearance of Two-State solution advocate Harvard Professor of Law Alan Dershowitz and then DePaul Professor Norman Finkelstein on Democracy Now! on 24 September 2003, in which the latter concluded, in connection with the former's new book THe CASE For IsRael, "Mr Dershowitz has concocted a fraud ... which amazingly, in large part, he plagiarized from another fraud. I found that pretty shocking." Dershowitz-Finkelstein Debate (Democracy Now!) (YouTube 2017), https:/ / www.youtube.com/watch?v=C6To-o-aiRg, at 10 minutes. Professor Finkelstein-himself the child of Nazi concentration camp survivors-has argued (at significant personal career cost) that the horror of the Holocaust has been hijacked into an ideology to protect the State of Israel and the role it plays in aiding US imperial domination of the Middle East. See NormAn G. FinKELSTEIN, The Holocaust Industry: Reflections on the Exploitation of Jewish Suffering (Second ed. Verso 2015).

Another example was the written exchange between Columbia Professor Jonathan Schorsch and NYU Professor Bertell Ollman, in which the latter writes of "a half century of Zionist assassinations, collective punishments, ethnic cleansing, imprisonments, tortures, cutting off life resources (of water, electricity, food, education, housing and jobs), and constant humiliations." Bertell Ollman, Love of IsRael? (Tikkun 2005), https://www.nyu.edu/projects/ollman/docs/love_of_israel.php.

See, also, the debate between Professor Dershowitz and MIT Professor Noam Chomsky at the Kennedy School of Government on 29 November 2005. Dershowitz vs Chomsky Debate Israel at Harvard (YouTube 2012), https://www.youtube.com/watch?v=3ux4JU_sbB0. 26 See Allan Gerson, Israel, the West Bank and International Law (First ed. Cass 1978). For access to various topical UN documents over 1947-2017, including selected Security Council Resolutions and General Assembly Documents, see UN Documents FOR IsRAEL/PALESTINE (Sec. Council Report 2018), http://www.securitycouncilreport.org/un-documents/israelpalestine/.

27 See Iris Agmon, Family \& Court: Legal Culture and Modernity in Late Ottoman Palestine (Syracuse Univ. Press 2005).

28 Ashkenazim, constituting the majority of worldwide Jewry, are diaspora Jews originating from Central and Eastern Europe, as contrasted with Sephardim (Jews from communities settled in the Iberian Peninsula) and Mizrahim (Jews from the Middle East); the third category is often conflated with Sephardim. 
29 Today, a similar scheme—-known as land grabbing—is used by global corporations and sovereign funds in Africa in their development of capitalist monoculture.

30 See Fritjof Capra \& Ugo Mattei, The Ecology of Law: Toward a Legal System in Tune with Nature and Community (First ed. BerrettKoehler 2015).

31 The Court (Int'l Court of Justice 2017), http:/ /www.icj-cij.org/en/court.

32 By Motion of 29 November 2012, the UN General Assembly granted to Palestine "non-member observer State status" with a motion passed by 138 Yes, 9 No, and 43 abstentions.

33 MATTEi \& NADER, op. cit. supra.

34 The attempt is to depoliticize politics. See a blatant example in Martin Edelman, Courts, Politics, and Culture in Israel (First ed. Univ. of Va. Press 1994).

35 See Ugo Mattei, The Cold War and Comparative Law: A Reflection on the Politics of Intellectual Discipline, 65 The Am. J. of Comp. L. 567-07 (2017), https://doi.org/10.1093/ajcl/avx024.

36 See Edward W. Said, Orientalism (Vintage Books ed. Random House 1979).

37 The most comprehensive and masterly discussion of the "common core" project remains, even after a half century, Introduction in RuDolf B. Schlesinger, 1 Formation of Contracts: A Study of the Common Core of Legal Systems (Oceana Publications 1968).

38 See the classic René David, Camille Jauffret-Spinosi \& Marie Goré, Les grands systèmes de droit contemporains (12th ed. Dalloz 2016). See, also, Ugo Mattei, Three Patterns of Law: Taxonomy and Change in the World's Legal Systems, 45 Tнe Aм. J. of Comp. L. 5-44 (1997), https://doi.org/10.2307/840958.

39 See Ugo Mattei \& luca G. Pes, Civil law and Common law: Toward Convergence? (Gregory A. Caldeira, Daniel Kelemen \& Keith E. Whittington eds., Oxford Univ. Press 2008), http:/ / www.oxfordhandbooks.com/view/10.1093/oxfordhb/9780199208425.001.0001/oxfordhb-9780199208425-e-15.

40 For a description of this notion, see William Elliott Butler, Soviet Law (Second ed. Butterworths 1988). See, also, John B. Quigley, Soviet Legal InNovation and the Law of the Western World (Cambridge Univ. Press 2012).

41 See Stephen Goldstein, Israel: Creating a New Legal System from Different Sources by Jurists from Different Backgrounds in EsIN ÖRÜcÜ, ELSPETH Attwooll \& SeAn Coyle, Studies in Legal Systems: Mixed And Mixing (Kluwer Law Int'1 1996) at 147.

42 See Israeli Constitutional Law in the Making (Gideon Sapir, Daphne Barak-Erez \& Aharon Barak eds., Hart Publ'g 2013) (Hart Studies in Comparative Public Law).

43 Edelman at 100.

44 David Carey Miller (South Africa: A Mixed System Subject to Transcending Forces in ÖRücü at 176) has recognized for South Africa what no one has pointed out for Israel: "The development of a sophisticated system of private law is on one assessment an insignificant feature of a overall legal context dominated by discriminatory and oppressive legislation." Stephen Goldstein does not mention this state of affairs in Israel; on the contrary, he considers Israeli public law "a bastion of the common law" (150).

45 See Eyal Benvenisti, Legal Dualism: The Absorption of the Occupied Territories into Israel (First ed. Westview Press 1990): “with the fiction of belligerent occupation Israel has succeeded in slowly absorbing the territories without having to share political or economic power with the local population resorting to a symbolic act of annexation" (58).

46 See Mattei, Three Patterns of Law: Taxonomy and Change in the World's Legal Systems, op cit. supra.

47 See, e. g., Menachem Finkelstein \& Yifat Tomer, The Israeli Military Legal System-Overview of the Current Situation and a Glimpse into the Future, 52 A.F. L. Rev. 137-68 (2002). Hajjar, op. cit. supra, notes in her important book on the Israeli military court system how counterhegemony can emerge: "it was Israel's enthusiasm for law and the ornate legalism of official discourse that catalyzed the development of local human rights movement that served as harbinger of legalistic resistance" (49). For one of the most dramatic and less acknowledged issues, see Amanda Cahill-Ripley, The Human Right to Water and Its Application in the Occupied Palestinian Territories (First ed. Routledge 2011).

48 See David Kretzmer, The Occupation of Justice: The Supreme Court of Israel and the Occupied Territories (State Univ. of New York Press 2002); Separate and Unequal: Israel's Discriminatory Treatment of Palestinians in the Occupied Palestinian Territories, 2010 Hum. RTs. Watch, 49 See Tilley, op. cit. supra.

50 See, in a broader context, Alain Dieckhoff, L'invention d'une nation: IsRä̈l et la modernité politique (Gallimard 1993).

51 See, among many, Gelpe, op. cit. supra, at 47, and Daniel Schorsch \& Uri Shoham, The Legal System of Israel, Legal Systems Cyclopedia Ch 6 Vol 5, 120-23. Israel is described as "firmly rooted in western conception of the rule of law" and contributing to the well known theory of empty land: "As a result of Mamluck destruction in the coastal plain this area remained almost empty of population until Jewish resettlement toward the end of the nineteenth century."

52 For another example of normalization, see The Seventh Joint Annual Exchange and Conference: Judicial Review in Comparative German-Israeli Perspective (Dirk Olzen \& Susanne Schwarz eds., Baden-Baden 2004).

53 See Yadin, Israel, in 1 International Encyclopedia of Comparative Law: National Reports (Mouton 1973), according to whom, “Within the community of western systems Israel private law may be classified as progressive" (79). See, also, in similarly "politically neutral" terms, S. Colombo, Israele, in 10 Digesto Discipline Privatistiche-Sezione Civile 201 (1993).

54 See Kretzmer.

55 Sophia Hoffman, A Sovereign for All: The Management of Refugees As Nation-State Politics, in The Politics of Humanitarianism: Power, IDEOlogy AND Aid (Antonio De Lauri ed., I. B. Tauris 2016) at 147.

56 For the historical roots of this argument, see CAPRA \& MATtEI,op. cit. supra.

57 This military superiority of the Zionist State has been maintained (and increased) to this day with the help of the United States.

58 PAPpé at 179.

59 See Lynn Etheridge Davis, The Cold War Begins: Soviet-American Conflict Over East Europe (Princeton Univ. Press 2016).

60 See Jerome Slater, The Superpowers and the Arab-Israeli Political Settlement: The Cold War Years, 105 PoL. Scr. Q. 557-77 (1990-91) at 558.

61 See Ramona Tausz, WATCH: The King David Hotel Bombing, 1946, The Times of Israel, 3 September 2015, http://www.timesofisrael.com/watch-the-king-david-hotel-bombing-1946/.

62 Similarly, the United States may have been motivated in part by the US Government's feelings of guilt:

World War II prompted the largest displacement of human beings the world has ever seen ... But even with millions of European Jews displaced from their homes, the United States had a poor track record offering asylum. Most notoriously, in June 1939, the German ocean liner St Louis and its 937 passengers, almost all Jewish, were turned away from the port of Miami, forcing the ship to return to Europe; more than a quarter died in the Holocaust.

Daniel A. Gross, The U.S. Government Turned Away Thousands of Jewish Refugees, fearing That They Were Nazi Spies, (Smithsonian 2015), https://www.smithsonianmag.com/history/us-government-turned-away-thousands-jewish-refugees-fearing-theywere-nazi-spies-180957324/. 
63 For a detailed discussion, see Ugo Mattei, The Cold War and Comparative Law: A Reflection on the Politics of Intellectual Discipline, op. cit. supra.

64 On the other hand, for descriptions of disagreements between the US and Soviet Nuremberg delegations, see MATTEI, RuskolA \& GiDI, op. cit. supra, at 837-38, and Francine Hirsch, The Soviets at Nuremberg: International Law, Propaganda, and the Making of the Postwar Order, 113 The Ам. Hist. Rev. 701-30 (2008), http:/ / www.jstor.org/stable/30223049 (the latter's detailing, based on then relatively new evidence from Soviet archives, how Nuremberg "became one of the first fronts of the Cold War" (726) and "was about politics that motivated the United States to pursue its postwar agenda through the [International Military Tribunal] at the expense of the Soviet Union" (730)).

See, generally (and comprehensively), Robert H. Jackson, Report of Robert H. Jackson, United States Representative to the International Conference on Military Trials: A Documentary Record of Negotiations of the Representatives of the United States of America, the Provisional Government of the French Republic, the United Kingdom of Great Britain and Northern Ireland, and the Union of Soviet Socialist Republics, Culminating in the Agreement and Charter of the International Military Tribunal (Dep't of State, United States of Am. 1949) (negotiations held June 26 to 8 August 1945, at which representatives "made formal statement of the principles of substantive law and agreed upon methods of procedure for the prosecution and trial of the major European war criminals"), https://www.loc.gov/rr/frd/Military_Law/pdf/jackson-rpt-military-trials.pdf.

See, also, Ophuls,op. cit. supra, at approximately 1 hour and 46 minutes, where chief prosecutor for the United Kingdom at Nuremberg Sir Hartley Shawcross recollects:

There was quite a big school of thought ... in the Soviet Union-when they came into the war-in favor of what was called executive action, which was that these [Nazi war criminals] should be caught and there should be a very short drumhead court martial and they would be executed out of hand in the morning. The Americans were very much opposed to this. Americans, in those days at any rate, had a great belief in the rule of law and in justice.

65 For a manifestation of "winner's justice" granting pre-eminence in US litigation to plaintiffs in the more recent complex Holocaust litigation, see Ugo Mattei \& Jeffrey Lena, U.S. Jurisdiction Over Conflicts Arising Outside of the United States: Some Hegemonic Implications, 24 Hastings Int'L \& Comp. L. Rev. 381-400 (2001).

66 G. Tedeschi \& Y. S. Zemach, Codification and Case Law in Israel, and U. Yadin, Judicial Lawmaking in Israel, at 272-95 and 296-310, respectively, in The Role of Judicial Decisions and Doctrine in Civil Law and in Mixed Jurisdictions (Joseph Dainow ed., La. State Univ. Press 1974).

67 See Agmon.

68 For descriptions of Jewish and Islamic legal traditions, see J. David Bleich \& Arthur J. Jacobson, The Jewish Legal Tradition, and Khaled Abou El Fadl, The Islamic Legal Tradition, in The CAmbridge Companion to Comparative LAw, 278-94 and 295-312, respectively (Mauro Bussani \& Ugo Mattei eds., Cambridge Univ. Press 2012).

69 See Burns H. Weston \& David Bollier, Green Governance: Ecological Survival, Human Rights, and the Law of the Commons (Illustrated ed. Cambridge Univ. Press 2013).

70 See Eduardo Galeano, Open Veins of Latin America: Five Centuries of the Pillage of a Continent (Reprint ed. NYU Press 1997).

71 See Eric R. Wolf, Europe and the People Without History (Second ed. Univ. of Cal. Press 2010).

72 See Karl Polanyi, The Great Transformation: The Political and Economic Origins of Our Time (Reprint ed. Beacon Press 2001).

73 For a description of "the so-called primitive accumulation," see Karl Marx, Capital: A Critioue of Political Economy, Volume I (Friedrich Engels ed., 1883), https://www.marxists.org/archive/marx/works/download/pdf/Capital-Volume-I.pdf at 523.

74 This approach can be traced to the early tradition of Karl Nickerson Llewellyn \& Edward Adamson Hoebel, The Cheyenne Way: Conflict and Case Law in Primitive Jurisprudence (Illustrated reprint ed. Univ. of Okla. Press 1941), the import of which book is described thus:

The book in its final form was groundbreaking in that it provided legal anthropology with a whole new direction in the study of conflicts rather than laws strictly understood ... [T] he teachings of legal realism spread to legal anthropology through the Manchester School and the teachings of Sally Falk Moore. What the book showed was how one could escape the vestiges of conceptualism and cultural hierarchies that earlier legal anthropology had relied upon.

† Kaius Tuori, American Legal Realism and Anthropology, 42 L. \& Soc. Inouiny 804-29 (2017) at 815.

75 See Elinor Ostrom, Governing the Commons (Reissue ed. Cambridge Univ. Press 2015).

76 See Nader, Culture and Dignity: Dialogues Between the Middle East and the West,op. cit. supra.

77 See MATTEi \& NADER.

78 For an introduction to the commons as an epistemological approach, see David Bollier, Think Like A Commoner: A SHort Introduction To the Life of the Commons (New Soc'y Publishers 2014).

79 Eisenhower Farewell Address (YouTube 2015), https:/ / www.youtube.com/watch?v=OyBNmecVtdU.

80 See Capra \& MATTEI.

81 Robert Frost, The Road Not Taken (Henry Holt 1916),

https://en.wikipedia.org/wiki/The_Road_Not_Taken\#/media/File:The_Road_Not_Taken_-_Robert_Frost.png.

82 See Laura Nader \& Elisabetta Grande, Current Illusions and Delusions About Conflict Management-In Africa and Elsewhere, 27 L. \& Soc. INQUIRY 573-91 (2002).

83 See Tilley, op. cit. supra; see, also, The Legal Status of the West Bank and Gaza (Comm. on the Exercise of the Inalienable Rights of the Palestinian People 1982), https:/ / unispal.un.org/DPA/DPR/unispal.nsf/0/9614F8FC82DCA5DF852575D80069E0C0.

84 For example, Daphne Barak-Erez goes as far as proposing Israel as a global model on how to handle security issues according to the rule of law. See Barak-Erez, The National Security Constitution and the Israeli Condition, op. cit. supra, at 429 . The normalization strategy is well exemplified in Olzen \& Schwarz.

85 See Seraj Assi, Why Kibbutzism Isn't Socialism, JAcoBIn (2017), https://www.jacobinmag.com/2016/10/kibbutz-labor-zionism-berniesanders-ben-gurion/.

86 See Michael Hardt \& Antonio Negri, Assembly, Oxford U.P. 2017; Massimo de Angelis, Omnia Sunt Communia: On the Commons and the Transformation to Postcapitalism (First ed. Zed Books 2017).

87 For some early steps in a social theory of the commons, see the forthcoming Mark Mancall \& Ugo MatteI, Communology, in Annuary of Law and Policy, Stanford 2018. 